\title{
COMPARISON OF EFFECTIVENESS OF CLUSTER MAPPING, FLOW CHARTING, AND DOUBLE/TRIPLE ENTRY ON TEACHING WRITING SKILL
}

\author{
Daniar Sofeny \\ Universitas Islam Darul 'Ulum \\ email: daniarsofeny@unisda.ac.id
}

\begin{abstract}
The study was aimedat examining the effectiveness of three writing techniques, namely Cluster Mapping, Flow Charting, and Double/Triple Entry in improving students' writing skills. The study used a descriptive comparative technique using a quantitative approach. It compared the equations and differences as phenomena to find factors/situations that can cause the occurrence of a particular event. The data collection techniques were documentation studies by taking the students' writing products and face-to-face interviews between the interviewer and the respondent using an interview guide. The try-out was conducted to measure validity and reliability. A two-way ANOVA was conducted to test the hypotheses, a two-way $F$-test at the 5\% $(0.05)$ level of significance. The subjects of the study were 22 fourth-semester English students. The English students' writing skills using three techniques were the objects of the study. The findings of the study showed that the average writing score of the Cluster Mapping was 56.5, the average writing score of the Flow Charting was 49.6, and the average score of the Double/Triple Entry was 63.0. It can be concluded that those three techniques of writing skill are effective to use but the most effective is the Double/Triple Entry technique.
\end{abstract}

Keywords: cluster mapping, flow charting, double/triple entry, writing skill

\section{PERBANDINGAN KEEFEKTIFAN CLUSTER MAPPING, FLOW CHARTING, DAN DOUBLE/TRIPLE ENTRY DALAM PEMBELJARAN MENULIS}

\begin{abstract}
Abstrak
Penelitian inibertujuan untuk menguji efektivitas tiga teknik keterampilan menulis, yaitu Cluster Mapping, Flow Charting, dan Double/Triple Entry dalam meningkatkan keterampilan menulis mahasiswa. Pendekatan penelitian yang digunakan adalah deskriptif kuantitatif. Subjek penelitian ini adalah mahasiswa semester empat jurusan bahasa Inggris dengan total 22 orang. Teknik pengumpulan data dilakukan lewat dokumentasi dengan mengambil produk tulisan mahasiswa dan wawancara. Teknik analisis data dilakukan dengan menggunakan teknik statistik anava dua jalan dengan taraf signifikansi 5\%. Keterampilan menulis mahasiswa bahasa Inggris menggunakan tiga teknik menjadi fokus yang diteliti. Temuan penelitian ini menunjukkan bahwa skor rata-rata menulis mahasiswa menggunakan cluster mapping adalah 56,5, skor ratarata tulisan mahasiswa menggunakan flow charting adalah 49,6, dan skor rata-rata
\end{abstract}


tulisan mahasiswa menggunakan double/triple entry adalah 63,0. Dengan demikian dapat disimpulkan bahwa ketiga teknik keterampilan menulis efektif digunakan, tetapi yang paling efektif adalah teknik double/triple entry.

Kata kunci: cluster mapping, flow charting, double triple entry, keterampilan menulis

\section{INTRODUCTION}

Language is one of the most important aspects of communication. Many people are trying to deepen the different languages of the world to make it easier to communicate. Communication itself is divided into two, namely direct and indirect communication. Direct communication can be done by talking to each other, while indirect communication in the form of writing.

One of the important languages that became the international language is English. In English there are 4 skills that must be mastered so that can communicate smoothly and easily, namely Speaking, Listening, Reading, and Writing. To be able to communicate directly then we must deepen speaking skills, while for indirect communication we must deepen writing skill. Reading and listening skills are in charge of supporting both skills.In this research, researcher will focus on skill writing because this skill becomes the most difficult skill to master. We know that step mastery of language skills from the easiest is the skill of speaking then listening then reading, and the last is writing. Writing becomes the most difficult and complex skill as expressed by Heaton (2008: 141) because writing in the slightest mistake will be easier to see than with direct communication.

In the student environment, especially students majoring in English, writing becomes a fundamental thing that must be mastered. The ability to write can affect the level of students' success. Having good writing skills can make it easier for them to write tasks on campus such as writing reports, resumes, final assignments (thesis), etc. For that reason it is necessary to give a technique in teaching writing so that the students can be better to understand how to write properly and correctly to express in writing the ideas, opinions, thoughts or feelings as said by Tarigan (2009: 5).

There are many techniques that can be implemented in teaching writing. Here the researcher will compare three techniques that have been proven effective for improving writing skills, namely Cluster Mapping, Flow Charting, and Double/Triple Entry. This is evident by several researches that have been done.The first research was conducted by Adriati (2013) with the research title is "The use of clustering mapping in teaching writing narrative text". She uses quasi experimental research techniques aimed at 60 high school students in 10th grade. Her research results show that clustering technique effective for use in teaching writing narrative text.

The second research was conducted by Sawitri, et al. (2014) with the title "Improving the Eleventh Grade Students' Ability in Writing Simple Cause Effects Sentences through 
Flow Chart. The research used true experimental research design with the result that Flow chart technique is effective to improve the ability of the eleventh grade students in writing simple cause and effect sentences. The third research was conducted by Mohammad Husein (2013) under the title "Enhancing Students' Motivation to write Essays through Brainstorming: A Comparative Research." Here the researchers use various brainstorming techniques one of them is Double/ Triple Entry. The results indicate that both types of brainstorming were motivated to learn more by preference given to guide brainstorming.

The three researches already mentioned have similarities and differences with the research that the researcher will do. The equation lies in the research variables that are three techniques to improve writing skill (cluster mapping, flow charting, and double/ triple entry). The difference is in this research the researcher will compare the effectiveness of those three techniques on teaching writing at the university level by finding one of the most effective technique to use, following the advantages and disadvantages.

From that background, the researcher is interested in doing research entitled "Comparison of Effectiveness of Cluster Mapping, Flow Charting, and Double/ Triple Entry on Teaching Writing Skill.

The purposes of this research are as follows: to show the application of Cluster Mapping technique in teaching writing skill to fourth semester students in English department, to show the application of Flow Chart technique in teaching writing skill to fourth semester students in English department, to show the application of the Double/Triple Entry technique in teaching writing skill to fourth semester students in English department, to show the most effective techniquefor use in teaching writing skill to fourth semester students in English department.

In this research will give the benefits theoretically, practically, and pedagogically. Theoretically, the result of this research supports the theory of techniques in teaching writing. It also can be used as a reference for conducting the research especially in teaching writing skill using the effective technique. Practically, the result of this research can give the benefits for the educators like teacher or lecturer in English, the students, and other researchers. For educators, it can be used to teach their students in teaching writing in order to improve their achievements in learning English as a foreign language. For students, it can be an effective technique to increase their achievement in learning English as a foreign language especially in writing skill. For other researchers, it can be a reference in the research related to teaching writing skill. Pedagogically, the result of this research will help the students to use the best technique in learning English as a foreign language especially in writing skill.

Clustering or mind mapping is a kind of technique which can be used in pre-writing stage. Itis introduced by Gabriele Lusser Rico, a professor of English and Creativity at San Jose State University, California in 1980s. It is a technique which provides analternative way for writers to do the brainstorming 
before starting to write.Ricoalso claims that clustering is a kind of technique in brainstorming which benefits greatly from the right brain (which she called, Design mind), the part of the brain in which non-linear pattern and images production occur(Folit, 2009). Likewise, Pica (Baroudy, 2008) defines clustering as a "non-linear brainstorming process that generates ideas, images, and feelings around a stimulus word until a pattern becomes discernible".

Doing clustering involves several simple steps which can be easily accomplished. First, it is started by writing down a word or phrase in the center ofa blank sheet and circling it.Next, it continues by immediately writing down related words or phrases which come into mind, circling each of them, and making line which connects each to the main, initial circle or bubble just like" spokes in a wheel" (Baroudy, 2008). Finally, writers may stop after the given time has passed, then they can examine the cluster to pick the subtopics that interest them most or are considered to be covered by their competence. Overall, the words or phrases in the cluster provide a starting point for writers to see and understand their world from a new perspective (Folit, 2009).

A flowchart is a diagram that depicts a process, system or computer algorithm. They are widely used in multiple fields to document, study, plan, improve and communicate often complex processes in clear, easy-to-understand diagrams. Flowcharts, sometimes spelled as flow charts, use rectangles, ovals, diamonds and potentially numerous other shapes to define the type of step, along with connecting arrows to define flow and sequence. They can range from simple, hand-drawn charts to comprehensive computer-drawn diagrams depicting multiple steps and routes. If we consider all the various forms of flowcharts, they are one of the most common diagrams on the planet, used by both technical and non-technical people in numerous fields. Flowcharts are sometimes called by more specialized names such as Process Flowchart, Process Map, Functional Flowchart, Business Process Mapping, Business Process Modeling and Notation (BPMN), or Process Flow Diagram (PFD). They are related to other popular diagrams, such as Data Flow Diagrams (DFDs) and Unified Modeling Language (UML) Activity Diagrams.

The Double-Entry Journal strategy enables students to record their responses to text as they read. Students write down phrases or sentences from their assigned reading and then write their own reaction to that passage. The purpose of this strategy is to give students the opportunity to express their thoughts and become actively involved with the material they read. Introduce a passage of text to the students. Discuss the Double-Entry Journal technique and model the procedure including specific guidelines for writing. Have students read the selected text making journal entries whenever a natural pause in the reading occurs, so that the flow is not interrupted constantly.

Double-Entry Journaling improves students' comprehension, vocabulary, and content retention. This interactive strategy activates prior knowledge and present feelings, and promotes collaborative learning. It fosters the connection between reading and 
writing as students are able to "reply" to the author or speaker as they write their responses. The technique offers flexibility in that teachers can use any form of written text, read alouds, or listenings that are assigned in class

\section{METHOD}

The research method which the researcher used is descriptive comparative technique with quantitative approach. The research using Comparative Study technique is done by comparing equations and differences as phenomena to find what factors/situations that can cause the occurrence of a particular event. This research begins by gathering facts about the factors that cause a particular symptom, and then compared. After knowing the similarities and differences of causes, then determined that a factor that causes the emergence of a symptom on the object under study, it is actually the cause of the emergence of these symptoms.

In this research, researcher will gather facts about the results of the application of three techniques in writing skills, namely cluster mapping, flow charting, and double/triple entry. After that the researcher will compare between the equation and the difference so it will be known what factors cause it. Finally the researcher will draw conclusions about the most effective techniques to apply.

The subject in this research is the students majoring in English education in the forth semester. Whereas the object is the students' writing skill using three techniques of writing. The reason for choosing the subject is because in the forth semester there is a creative writing course that teaches students about writing skills that are more complex. The results of the application of the three techniques that will give researcher will be more significant because the students have passed the simple writing to the extensive writing course.

There are two important things that affect the quality of data research results, namely the quality of instruments and quality of data collection.

Data collection techniques used in this research are: Documentation study is a technique of collecting data by collecting and analyzing documents among written, drawing and electronic. In this research take documentation of student writing product after applying three writing skill techniques, those are cluster mapping, flow charting, and double/triple entry. The second is interview. It is the process of obtaining information for the purpose of research by means of question and answer while face to face between the questioner or the interviewer with the answering or respondent using a tool called interview guide (interview guide). Interview technique in this research is intended for students majoring in English language education in the forth semester. This interview uses some questions that researcher has prepared before.

The data analysis in this study was conducted over the course of the study. The data analysis conducted to the data from the product result of students' writing after the implementation of three techniques of writing skills. The data was analyzed using analysis of variance (ANOVA). To test the hypotheses, two-way analysis of variance with $F$-test at the .05 level 
of significance was used. Two-way ANOVA requires two basic things including normal distribution score for each sell and homogeneity of the score variation.

\section{FINDING AND DISCUSSION Findings}

This study was conducted in four meetings. The allocation of time in each meeting is $2 \times 50$ minutes or equal to two credits. All students are active and present at $100 \%$ at each meeting, amounting to 22 students. In assessing the results of the writing of these students, researcher used the writing assessment model according to Brown (2017) which included content, organization, syntax, vocabulary, and mechanics.

The Table 1 presents the assessment result of students' writing after applying the Cluster Mapping Technique. It assesed based on four components of Brown Model, C (Content), O (Organization), S (Syntax), V (Vocabularies), and M (Mechanics).

The average score of students' writing using Cluster Mapping is under the normal score $(56,6)$. The maximum score is 100 . So, the normal score should be 70 . In applying this technique, there are only three students get the normal Score and the others are still under the normal.

Table1. Assessment Results Writing with the Cluster Mapping Technique

\begin{tabular}{clcccccc}
\hline \multirow{2}{*}{ No } & Name & \multicolumn{5}{c}{ Component } & Total \\
\cline { 3 - 6 } & & $\mathbf{C}$ & $\mathbf{O}$ & $\mathbf{S}$ & $\mathbf{V}$ & $\mathbf{M}$ & \\
\hline 1 & AS & 15 & 10 & 5 & 5 & 5 & 40 \\
2 & YF & 20 & 15 & 8 & 10 & 10 & 63 \\
3 & FK & 22 & 15 & 10 & 10 & 10 & 67 \\
4 & NA & 22 & 15 & 10 & 10 & 10 & 67 \\
5 & YES & 22 & 18 & 10 & 10 & 10 & 70 \\
6 & DF & 15 & 10 & 5 & 7 & 5 & 42 \\
7 & AA & 22 & 18 & 11 & 11 & 11 & 72 \\
8 & SL & 22 & 18 & 11 & 11 & 11 & 72 \\
9 & DN & 15 & 15 & 8 & 10 & 11 & 59 \\
10 & HN & 10 & 10 & 10 & 10 & 10 & 50 \\
11 & DL & 15 & 10 & 8 & 7 & 10 & 50 \\
12 & INS & 15 & 10 & 8 & 10 & 10 & 53 \\
13 & W & 10 & 15 & 10 & 10 & 10 & 55 \\
14 & GP & 15 & 10 & 8 & 10 & 11 & 54 \\
15 & S & 15 & 10 & 10 & 10 & 10 & 55 \\
16 & AR & 10 & 10 & 8 & 7 & 10 & 45 \\
17 & NF & 15 & 15 & 8 & 10 & 10 & 58 \\
18 & ANA & 15 & 10 & 10 & 10 & 10 & 55 \\
19 & NR & 10 & 10 & 8 & 10 & 11 & 49 \\
20 & HPN & 15 & 10 & 10 & 10 & 11 & 56 \\
21 & QA & 15 & 15 & 8 & 7 & 10 & 55 \\
22 & NR & 15 & 15 & 8 & 10 & 10 & 58 \\
\hline & Tot. & $\mathbf{3 5 0}$ & $\mathbf{2 8 4}$ & $\mathbf{1 9 2}$ & $\mathbf{2 0 5}$ & $\mathbf{2 1 6}$ & $\mathbf{1 2 4 5}$ \\
\hline & Average & $\mathbf{1 5 , 9}$ & $\mathbf{1 2 , 9}$ & $\mathbf{8 , 7}$ & $\mathbf{9 , 3}$ & $\mathbf{9 , 8}$ & $\mathbf{5 6 , 6}$ \\
\hline
\end{tabular}


Then, the researcher uses Kolmogorov's normality test to test the normality of the data. Hereis the test results.

\begin{tabular}{|c|c|}
\hline Statistik & Var I \\
\hline N Sampel & 22 \\
\hline Mean & 56,591 \\
\hline Simpangan Baku & 9,048 \\
\hline D $_{\mathrm{n}}=$ & 0,122 \\
\hline KS Tabel & 0,290 \\
\hline \multicolumn{2}{|c|}{ Normal }
\end{tabular}

From the statistik above we can see that $\mathrm{Dn}(0,122)<\mathrm{KS}(0,290)$. So it means that the data of the students' writing using cluster mapping technique is distributed normal.
Table 2 which presents about the students' writing using flow charting technique and the assessment using Brown Model.

From those data it can be concluded that the use of Flow Charting Technique gets the lower score than the use of the previous Cluster Mapping. Here, there is also no students achieve the normal score. The lowest score is similar with the lowest score in using the cluster mapping technique, that is 40 .

Based on Kolmogorov's normality test, the data proved to be normally distributed. Hereis the test results:

Table 2. Assessment Results Writing with the Flow Charting Technique

\begin{tabular}{|c|c|c|c|c|c|c|c|}
\hline \multirow{2}{*}{ No. } & \multirow{2}{*}{ Name } & \multicolumn{5}{|c|}{ Component } & \multirow{2}{*}{ Tota } \\
\hline & & C & O & $\mathbf{S}$ & V & $\mathbf{M}$ & \\
\hline 1 & AS & 15 & 12 & 10 & 10 & 7 & 54 \\
\hline 2 & YF & 10 & 10 & 5 & 10 & 5 & 40 \\
\hline 3 & FK & 15 & 12 & 8 & 5 & 10 & 50 \\
\hline 4 & NA & 15 & 10 & 10 & 10 & 7 & 52 \\
\hline 5 & YES & 10 & 12 & 5 & 10 & 5 & 42 \\
\hline 6 & $\mathrm{DF}$ & 15 & 10 & 8 & 5 & 10 & 48 \\
\hline 7 & AA & 15 & 12 & 10 & 10 & 7 & 54 \\
\hline 8 & SL & 10 & 10 & 5 & 10 & 5 & 40 \\
\hline 9 & DN & 15 & 10 & 8 & 5 & 5 & 43 \\
\hline 10 & HNHS & 22 & 17 & 10 & 10 & 10 & 69 \\
\hline 11 & DL & 15 & 10 & 5 & 10 & 7 & 47 \\
\hline 12 & INS & 15 & 10 & 5 & 5 & 5 & 40 \\
\hline 13 & W & 10 & 15 & 10 & 10 & 5 & 50 \\
\hline 14 & GP & 22 & 18 & 11 & 11 & 11 & 72 \\
\hline 15 & $\mathrm{~S}$ & 20 & 12 & 10 & 10 & 5 & 57 \\
\hline 16 & ARW & 15 & 12 & 10 & 10 & 7 & 54 \\
\hline 17 & NF & 10 & 10 & 5 & 10 & 5 & 40 \\
\hline 18 & ANA & 15 & 12 & 8 & 5 & 10 & 50 \\
\hline 19 & NR & 15 & 10 & 10 & 10 & 7 & 52 \\
\hline 20 & HPN & 10 & 12 & 5 & 10 & 5 & 42 \\
\hline 21 & QA & 15 & 10 & 8 & 5 & 10 & 48 \\
\hline \multirow[t]{3}{*}{22} & NR & 15 & 12 & 10 & 10 & 7 & 54 \\
\hline & Total & 319 & 258 & 158 & 191 & 155 & 1099 \\
\hline & Average & 14,5 & 11,7 & 7,2 & 8,7 & 7,0 & 49,6 \\
\hline
\end{tabular}




\begin{tabular}{|c|c|}
\hline Statistik & Var I \\
\hline N Sampel & 22 \\
\hline Mean & 52,909 \\
\hline Simpangan Baku & 6,125 \\
\hline $\mathrm{D}_{\mathrm{n}}=$ & 0,200 \\
\hline KS Tabel & 0,290 \\
\hline \multicolumn{2}{|c|}{ Normal }
\end{tabular}

From the statistik above we can see that Dn $(0,200)<\mathrm{KS}(0,290)$ so it means that the data is distributed normal.

The last table, Table 3 presents the students writing using Double/ Triple Entry Technique.

The lowest score is higher than the lowest score in the use of cluster mapping and flow charting. It can be seen also that there are six students get the normal score. Different with the use of cluster mapping only three students.
It means that the use of double/triple entry is the most effective technique.

The the Kolmogrov's normality test used to test the normality of the data using double/triple entry. Here is the test result.

\begin{tabular}{|c|c|}
\hline Statistik & Var I \\
\hline N Sampel & 22 \\
\hline Mean & 62,818 \\
\hline Simpangan Baku & 7,359 \\
\hline $\mathrm{D}_{\mathrm{n}}=$ & 0,210 \\
\hline KS Tabel & 0,290 \\
\hline \multicolumn{2}{|c|}{ Normal }
\end{tabular}

From the statistik above we can see that Dn $(0,210)<\mathrm{KS}(0,290)$ so it means that the data is distributed normal.

Table 3. Assessment Results Writing with the Double/ Triple EntryTechnique

\begin{tabular}{|c|c|c|c|c|c|c|c|}
\hline \multirow{2}{*}{ No. } & \multirow{2}{*}{ Name } & \multicolumn{5}{|c|}{ Component } & \multirow{2}{*}{ Total } \\
\hline & & C & $\mathbf{O}$ & $\mathbf{S}$ & V & $\mathbf{M}$ & \\
\hline 1 & AS & 15 & 18 & 11 & 11 & 11 & 66 \\
\hline 2 & YF & 15 & 10 & 7 & 11 & 10 & 53 \\
\hline 3 & FK & 22 & 10 & 9 & 8 & 11 & 60 \\
\hline 4 & NA & 22 & 18 & 11 & 9 & 11 & 71 \\
\hline 5 & YES & 15 & 10 & 11 & 11 & 11 & 58 \\
\hline 6 & DF & 15 & 10 & 7 & 11 & 10 & 52 \\
\hline 7 & AA & 15 & 18 & 9 & 8 & 11 & 62 \\
\hline 8 & SL & 22 & 10 & 11 & 9 & 11 & 63 \\
\hline 9 & DN & 22 & 10 & 11 & 11 & 11 & 65 \\
\hline 10 & HNHS & 15 & 18 & 7 & 11 & 10 & 63 \\
\hline 11 & DL & 15 & 10 & 9 & 8 & 11 & 55 \\
\hline 12 & INS & 15 & 10 & 11 & 9 & 11 & 56 \\
\hline 13 & W & 22 & 18 & 11 & 11 & 11 & 73 \\
\hline 14 & GP & 22 & 10 & 7 & 11 & 10 & 60 \\
\hline 15 & S & 15 & 10 & 9 & 8 & 11 & 53 \\
\hline 16 & ARW & 22 & 18 & 11 & 11 & 11 & 72 \\
\hline 17 & NF & 22 & 18 & 11 & 11 & 11 & 72 \\
\hline 18 & ANA & 15 & 18 & 11 & 11 & 11 & 66 \\
\hline 19 & NR & 15 & 10 & 7 & 9 & 10 & 51 \\
\hline 20 & HPN & 22 & 18 & 11 & 11 & 11 & 72 \\
\hline 21 & QA & 22 & 18 & 11 & 11 & 11 & 72 \\
\hline \multirow[t]{3}{*}{22} & NR & 22 & 18 & 9 & 8 & 11 & 68 \\
\hline & Tot. & 407 & 308 & 212 & 219 & 237 & 1387 \\
\hline & Average & 18,5 & 14 & 9,6 & 9,9 & 10,8 & 63,0 \\
\hline
\end{tabular}


The last, the researcher perfoms the students' writing result in a Graph to make easier in comparing these used three technique. It can be shown in Graph 1.

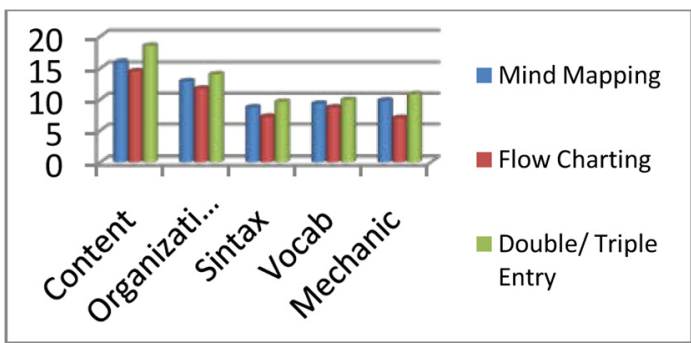

\section{Graph 1. Graph of Achieving Writing Skills by Using Three Techniques}

The three techniques in writing skills, namely mind mapping in blue, flow charting in red, and double/ triple entry in green, the green chart looks higher for all components compared to the others. Others are blue and red. The green graph that represents the writing results of students using the double/ triple entry technique.
The results of the analysis data to test for normality shows that all data obtained from the use of the three techniques is normally distributed because the significance value of $\mathrm{HO}>$ 0.05. And for the homogeneity test results show that all data is not different or homogeneous. To test the hypothesis shows that $\mathrm{HO}$ is accepted and $\mathrm{Ha}$ is rejected.

Some assumption of Anova test have been completed, like samples come from independent groups, Variants between groups must be homogeneous, Each group's data is normally distributed.

Then, the researcher do ANOVA test using one single factor. The result of the data as showed in Table 4.

$\mathrm{P}$-value showed 0,000017 . It is lower than 0,05 . So, it can be concluded that there is differences result score among those three techniques (mind mapping, flow charting, double/triple entry)

Table 4. Result of ANOVA Test Using One Single Factor

\begin{tabular}{|c|c|c|c|c|c|c|}
\hline \multicolumn{7}{|l|}{ Anova: Single Factor } \\
\hline \multicolumn{7}{|l|}{ SUMMARY } \\
\hline Groups & Count & Sum & Average & Variance & & \\
\hline Column 1 & 22 & 1245 & 56,59091 & 81,87229 & & \\
\hline Column 2 & 22 & 1098 & 49,90909 & 74,27706 & & \\
\hline Column 3 & 22 & 1383 & 62,86364 & 55,07576 & & \\
\hline \multicolumn{7}{|l|}{ ANOVA } \\
\hline Source of Variation & SS & $d f$ & $M S$ & $F$ & $P$-value & F crit \\
\hline Between Groups & 1846,636 & 2 & 923,3182 & 13,11376 & $1,73 \mathrm{E}-05$ & 3,142808517 \\
\hline Within Groups & 4435,727 & 63 & 70,40837 & & & \\
\hline Total & 6282,364 & 65 & & & & \\
\hline
\end{tabular}




\section{Discussion}

The discussion here presents the findings based on the data which has found.

\section{The Use of the Mind Mapping Technique}

Most students do writing activities not using techniques. They just put out the ideas they get for later being made into a writing based on a predetermined theme. Students have only learned about the genre of text so that in writing they can use the format according to the type of text that has been determined. However, they forgot to learn the technique of writing technique so that they could facilitate them in pouring ideas into writing.

In the first time new students find out the type of Mind Mapping technique used in this study. Based on the scores of students writing using this technique, their average score was 56.5 out of 5 assessment components. This category is included in the medium category.

The students feel helped by using this technique because the technique of mind mapping is to map the thinking according to the focus of the theme then from mapping the idea it will be easier to develop it into paragraphs. They also feel more creative in developing their thought ideas. However, they also encountered difficulties in using this technique such as: difficulties in developing English vocabulary, too long to determine ideas related to predetermined themes, and ideas that grew wider.

So, based on the data it can be concuded that the technique of Mind Mapping is effective to use.

\section{The Use of of Flow Charting Technique}

In applying the Flow Charting technique, many students encounter difficulties. However, their average writing score is still classified as medium category, which is 49.6. The mean is lower than the average writing score using the Mind Mapping technique. The technique in using this technique is to take a path in the direction of a predetermined theme. Students still have difficulties with the development of English vocabulary that they must use in preparing sentences according to the path they have chosen. Their writing results are less creative and developing because they only focus on one plot they have chosen. With a lower mean score compared to the previous technique, this technique is found to be less effective for students to use.

So, it can be concluded that the technique of flow charting is effective to use but the average score is lower than the use of mind mapping technique.

\section{The Use of the Double/ Triple Entry Technique}

Double/triple entry is the third or the last technique applied in this study. In its implementation, students seem to enjoy their writing activities more. And the average score obtained was 63.0. This proves that the double/triple entry technique has the highest average score compared to the two previous techniques, namely mind mapping and flow charting. According to students, the double/triple entry technique is younger to use because the development of the idea is broader but not out of line. Because in principle the technique in this technique is to bring up several groups 
of predetermined themes, then from the groups that have been created that will then be developed into paragraphs. In the use of vocabulary, students are also more helpful because there are already group discussion groups developed.

So, it can be concluded that the technique of Double/Triple Entry is effective to use. Comparing with Mind Mapping and Flow Charting technique, the average score for Double/ Triple entry is highest.

\section{The Most Effective Technique}

Based on the results of the students' writing scores that have been obtained after using the three writing techniques, the average score is known. For the average score, the use of mind mapping technique was 56.5, while the average score of the use of Flow Charting technique was 49.6 , and the average score of using the double/triple entry technique was 63.0. It can be concluded that the double/triple entry technique is the most effective to use than the mind mapping and flow charting technique.

The previous research related to this research which concern to Improving Writing Skill also has been conducted by Muluneh (2018) entitled Improving Students' Paragraph Writing Skill through Task-Based Approach. His journal has been published in Arts and Social Sciences Journal (OMICS International) scopus indexed. The differences between his research and this research is on the technique used in improving the writing skill. Muluneh uses Task-based approach in teaching writing the students which againts the type of communiative language teaching in India. He found that task based approach can improve the writing skill of the students by using experimental studies. Where as this research uses Three techniques which againts the type of communicative language teaching also but the subject is Indonesian university students.

Further, this current studies can also be the next experimental research by doing as the concept of Muluneh's research for Indonesians students.

\section{CONCLUSIONS}

Based on the results achieved from this study, the researchers can conclude the following.

The technique of mind mapping, flow charting, and double/ triple Entry are three of the many writing techniques that can be used in improving writing skills. Mind mapping is an effective technique used by students because the techniques used are easier to develop ideas based on predetermined themes. Flow charting is an effective technique used by students but it feels less effective because they encounter some difficulties such as the use of vocabulary and the development of monotonous sentences with only one plot. Double/triple entry is an effective technique used by students because the techniques used to develop their writing ideas are easier. Double/triple entry is the most effective technique compared to the mind mapping and flow charting techniques.

\section{ACKNOWLEDGEMENTS}

Researchers do say thanks to LPPM Unisda Lamongan who have provided funding for this research activity. The researchers also expressed their gratitude to the Directorate of Research and Community Service Director 
General of Research and Development Strengthening the Ministry of Research, Technology and Higher Education for those who have funded this research.

\section{REFERENCES}

Adriati, M. (2013). The Use of Clustering Technique in Teaching Writing Narrative Text. Journal of English and Education. Vol 1 No. 2, p. 39 - 46. From: http://ejournal. upi.edu/index.php/L-E/article/ view/582

Baraoudy, I. (2008). A Procedural Approach to Process Theory of Writing: Pre-Writing Techniques. The International Journal of Language Society and Culture, 24.

Brown, H. (2017). Principles of Language Learning and Teaching. 4th ed. White Plains, Sherrill: Addison Wesley Longman

Folit, R. (2009). Gabriele Lusser Rico Talks about the Benefits of Journaling. [Online]. Available at: http:// blog.lifejoural.com/2009/06/12/ gabriele-lusser-rico-talks-about-thebenefits-of-journaling/[Oktober 7, 2012]

Hairston, M. (1986). Contemporary Composition. Boston: Houghton Mifflin Company.

Hussein A.A. \& Fawzi. M.M. (2013).. Enhancing Students' Motivation to Write Essays through Brainstorming: A Comparative Study, International Journal Humanities and Social Science, 3(9), 191-196, www. ijhssnet.com/journals/Vol_3_ No_9_May_2013/18.pdf.

Inman, B.A. \& Gardner, R.(1979). Aspects of Composition. New York: Harcourt Brace Javanovich, Inc.
Langan, J. (1986). College Writing Skills. Singapore: McGraw-Hill Book Company.

Langan, J. (1987). Sentence Skills. New York: McGraw-Hill Book Company.

McCrimmon, J. M. (1984). Writing With a Purpose.Boston: Houghton Mifflin Company.

Mulune, T.K. (2018). Improving Students' Paragraph Writing Skill trough Task Based Approach. Art and Social Sciences Journal, 9(351), DOI:10.4172/2151-6200.1000351.

O'Malley, J.M. \& Chamot, A.U.(1990). Learning Strategies in Second Language Acquisition. Cambridge: Cambridge University Press.

Olson, C. B. (1992). Thinking Writing: Fostering Critical Thinking through Writing. New York: Harper Collins Publishers, Inc.

Oshima, A. \& Hogue, A.(1991). Writing Academic English. New York: Addison-Wesley Publishing Company, Inc.

Oshima, A. \& Hogue, A.(2007). Introduction to Academic Writing. New York: Pearson Education, Inc.

Oxford, R. L. (1990). Language Learning Strategy: What Every Teacher Should Know. New York: Newsbury House Publishers.

Rico, GL. (2000). Writing the Natural Way. [Online]. Available at: http: / / www. a mazon.com / reader $/ 0874779618$ ?_encoding $=\mathrm{U}$ TF8\&page=28\#reader_087477961 8[December16, 2012.

Sawitri. (2014). Improving the Eleventh Grade Students Ability in Writing Simple Cause Effect Sentences Through Flow Chart. e-journal of English Language Teaching Society 
(ELTS), 2(1), 1-14. DOI. 10.22487/ j23341841.2014.v2.i1.3018.

Tarigan, D. (2009). Writing is a Language Skills. Angkasa: Bandung.
Winarto, A. E.(2015).Training of Learning Strategies in Writing Essay. Journal of English Education and Linguistics Studies (JEELS). 2(2), 1-10. DOI: $10.30762 /$ jeels.v2i2.96. 